TABLE A2 - Independen variables significantly associated with still-birth or neonatal death excluded from model because of covariance

Height of mother

Number of previous premature births

Haemoglobin concentration

Duration of first stage of labour

Maternal age

Fetal distress (cord/prolapse/

meconium/fetal heart)

meconium/tetal heart)
Social and economic status

Social and economic status
Fever/tonsillitis/laryngitis

Fever/tonsillitis/laryngitis
Urinary tract infection

Urinary tract infection

Type of resuscitation
Prescription of drugs to baby

Prescription

Streptomycin included in the model that optimally estimates the log odds of stillbirth or neonatal death in the whole British perinatal mortality survey (1958) cohort. This list of variables includes the names of categorical variables together with the design variables that are generated (for example, "parity" is a categorical variable with four categories and hence three design variables labelled as " 1 ", “2", “3”), as well as their coefficients. Categorical variables with two categories have been listed in table A2 as having only a single entry in the model. No interactions were included in the model owing to the computational problems that these would have generated for little improvement of the model.

1 Hare EH. Epidemiology of schizophrenia and affective psychoses. Br.Med Bull 1987:43:514-30

2 Eaton WW. Epidemiology of schizophrenia. Epidemiol Rev 1985;7:105-26.

3 Weissman MM, Bovd JH. The epidemiology of affective disorders. In: Post RM, Ballenger JC, eds. Neurobiology of mood disorders. Baltimore: W'illiams and Wilkins, 1984:60-75.

4 Gottesman II, Shields J. Schizophrenia and genetics: a twin vantage point New York: Academic, 1972

5 Kendler KS, Robinette CD. Schizophrenia in the NAS-NRC twin registry: a 16 year update. Am F Psychiatry 1983;140:1551-63.

6 Bertelsen A, Harvald B, Hauge M. A Danish twin study of manic-depressive disorders. Br f Psychiatry 1977;130:330-51.

7 Kety SS. Mental illness in the biological and adoptive relatives of schizophrenic adoptees: findings relevant to genetic and environmental factors in etiology. Am J Psychiatry 1983;140:720-7.

8 Mendelwicz J, Rainer JD. Adoption study supporting genetic transmission in manic-depressive illness. Nature 1977;268:327-9.

9 Woerner MG, Pollack M, Klein DF. Pregnancy and birth complications in psychiatric patients: a comparison of schizophrenic and personality disorder psychiatric patients: a comparison of schizophrenic and personality

$10 \mathrm{McNeil} \mathrm{TF}$, Kaij L. Obstetric factors in the development of schizophrenia complications in the births of preschizophrenics and in reproduction by schizophrenic patients. In: Wynne LC, Cromwell RL, Matthysse S, eds. The nature of schizophrenia. New York: Wiley, 1978:401-29.

11 Lewis SW, Murray RM. Obstetric complications, neurodevelopmental deviance and risk of schizophrenia. $\mathcal{F}$ Psychiat Research 1987;21:413-22.

2 Dalen P. Family history, the electroencephalogram, and perinatal factors in manic conditions. Acta Psychiatr Scand 1965;41:527-63.

13 Lane EA, Albee GW. Comparative birth weights of schizophrenics and their siblings. F Psychology 1966;64:227-31.

14 Pollack M, Woerner M, Goodman W, Greenberg I. Childhood development patterns of hospitalised adult schizophrenic and non-schizophrenic patients and their siblings. Am J Orthopsychiatry 1966;36:510-97.

15 Pollack M, Levenstein S, Klein DF. A three year post-hospital follow-up of adolescent and adult schizophrenics. Am f Orthopsychiatry 1968;38:94-109.
16 Jacobsen B, Kinney DK. Perinatal complications in adopted and non-adopted schizophrenics and their controls: preliminary results. Acta Psychiatr Scand 1980;62(suppl 285):337-46.

17 Owen MJ, Lewis SW, Murray RM. Obstetric complications and schizophrenia: a computer tomographic study. Psychol Med 1988;18:331-9.

18 Olson SC, Nasrallah HA, Coffman JA, Schwarzkopf SB. Perinatal complications and premorbid function in psychosis. Biol Psychiatry 1989;25: 93-106A.

19 Reddy R, Mukheriee S, Schnur D. Pregnancy and birth complications and premorbid functioning in schizophrenic and bipolar patients. Bio Psychiatry 1989;25:93A.

20 Eagles JM, Gibson I, Bremner MH, Clunie F, Ebmeier KP, Smith NC. Obstetric complications in DSM-III schizophrenics and their siblings. Lancet 1990;336:1139-41.

21 Joffe M, Grisso JA. Comparison of antenatal hospital records with retrospective interviewing. I Biol Science 1985;17:113-9.

22 Lewis SW. Congenital risk factors for schizophrenia. Psychol Med 1989;19. 5-13.

23 Parnas J, Schulsinger F, Teasdale TW, Schulsinger H, Feldman PM, Mednick SA. Perinatal complications and clinical outcome within the schizophrenia spectrum. Brf Psychiatry 1982;140:416-20.

24 Wrede G, Mednick SA, Huttunen MO, Nilsson CG. Pregnancy and delivery complications in the births of an unselected series of Finnish children with schizophrenic mothers. Acta Psychiatr Scand 1980;62:369-81.

25 Mednick SA, Mura E, Schulsinger F, Mednick B. Perinatal conditions and infant development in children with schizophrenic parents. Soc Biol 1971; 18:103-13.

26 Mirdal GKM, Mednick SA, Schulsinger F, Fuchs F. Perinatal complication in the children of schizophrenic mothers. Acta Psychiatr Scand 1974;50 553-68

$27 \mathrm{McNeil}$ TF, Kaij L. Obstetric complications and physical size of offspring of schizophrenic, schizophrenic-like, and control mothers. Br $\mathcal{F}$ Psychiatry 1973;123:341-8.

28 Shepherd PM. The national child development study. An introduction to the background to the study and methods of data collection. London: Social Statistics Research Unit, City University, 1985. (Working paper No 1.)

29 Wing JK, Cooper JE, Sartorius N. The measurement and classification of psychiatric symptoms: an instruction manual for the PSE and CATEGO psychiatric symptoms: an instruction manual for the

30 Gottesman II, Shields J. Schizophrenia: the epigenetic puzzle. Cambridge University Press, 1982.

31 Der G, Gupta S, Murray RM. Is schizophrenia disappearing? Lance 1990;335:513-6.

32 Butler N, Alberman ED. Perinatal problems. Edinburgh: Livingston, 1969.

33 Butler N, Goldstein H, Ross EM. Cigarette smoking in pregnancy: influence on birth and perinatal mortality. $B M \mathcal{F} 1971 ; \mathrm{i}: 127-30$.

34 Mednick SA. Berkson's fallacy and high risk research. In: Wynne LC Cromwell RC, Matthysse S, eds. The nature of schizophrenia. New York: Wiley, 1978:442-52.

(Accepted 18 April 1991)

\section{Infant feeding practices and ulcerative colitis in childhood}

\author{
S|Koletzko, A Griffiths, MYCorey, GSmith, \\ PSherman
}

\section{Division of \\ Gastroenterology, \\ Departments of Paediatrics \\ and Nursing, Research \\ Institute, Hospital for Sick \\ Children, University of \\ Toronto, Toronto, Canada \\ M5G 1X8}

S Koletzko, MD, research

fellow

A Griffiths, MD, assistant

professor

M Corey, MSC, statistician

C Smith, RN, gastroenterology

nurse

P Sherman, $\mathrm{MD}$, associate

professor

Correspondence to:

Dr Sherman.

BMF 1991;302:1580-
Accumulating evidence indicates that events early in life, including infant feeding practices, can have long term effects on health and disease. ${ }^{1}$ We recently showed that the absence of breast feeding and early diarrhoea are independent risk factors associated with development of Crohn's disease later in childhood. ${ }^{2}$ To determine if similar risk factors were linked to the development of ulcerative colitis we carried out an epidemiological case-control study.

\section{Patients, methods, and results}

A questionnaire was sent to 118 families with at least one child with ulcerative colitis diagnosed by endoscopic and histological criteria. Data obtained included age, sex, premature delivery, diarrhoeal illnesses during the first six months of life, type of feeding used from birth, duration of exclusive breast feeding, total duration of breast feeding, and the age at which solids were introduced. As in our previous study breast feeding referred to any provision of human milk and exclusive breast feeding indicated the absence of formula milk and solids. ${ }^{2}$ Unaffected siblings served as controls to reduce the variation of genetic factors and confounding variables. Potential risk factors were analysed within families by using the conditional logistic regression model. ${ }^{2}$
Of the 118 families, $108(92 \%)$ completed the questionnaires. This included 17 children without unaffected siblings, leaving 93 affected children and 138 siblings available for analysis. The mean $(14 \cdot 2$ (SD $4 \cdot 1)$ years) and median ( 15.0 years) ages for children with ulcerative colitis were comparable with those of the group of unaffected siblings $(15 \cdot 7$ $(6 \cdot 5) ; 15 \cdot 8)$.

Multivariate analysis showed that children with ulcerative colitis were more likely to have had diarrhoeal diseases during infancy (relative risk 3.2 $(95 \%$ confidence limits $1 \cdot 15$ to $8 \cdot 75$ ), $p=0.03$ ) compared with their unaffected siblings. Female sex was also an independent risk factor $(2.3(1.23$ to 4.35$), p=0.01)$. In contrast to our previous findings for childhood Crohn's disease, ${ }^{2}$ absence of breast feeding was not significantly different among children with ulcerative colitis $(1.7$ $(0.77$ to 3.65$), p=0 \cdot 19)$. Duration of exclusive breast feeding, total length of breast feeding, and age at introduction of solid foods did not differ between children with ulcerative colitis and their siblings. Birth order and the incidence of premature delivery were comparable in the two groups.

\section{Comment}

In this study the lack of breast feeding and presence of formula feeding were not identified as risk factors for the development of childhood ulcerative colitis. This finding agrees with the results of one study $^{3}$ but contrasts with two studies in adults with ulcerative colitis $^{45}$ and our previous observation of paediatric Crohn's disease. ${ }^{2}$ Our study design reduces the possibility of recall bias because parents completed the questionnaires for both cases and controls. In addition, 
the question of whether or not a child was ever breast fed is not subject to major recall error. The length of time elapsed before obtaining data was less for our paediatric patients than in studies in adults. ${ }^{45}$

It is possible that the aetiologies of Crohn's disease and ulcerative colitis are distinct and that breast feeding exerts a protective effect only in Crohn's disease. Alternatively, a small protective effect of breast feeding in preventing later ulcerative colitis may not have been identified by the number of patients entered into this study (type II error).

As in our previous study of childhood Crohn's disease, diarrhoeal illness during infancy was identified as an independent risk factor for subsequent development of ulcerative colitis. Infectious diarrhoea could increase exposure of the enteric immune system to luminal antigens,' leading to enhanced or altered immune responses against dietary and microbial antigens later in life. It is possible, however, that recall bias accounted for the difference observed between the two groups as parents might remember previous intestinal symptoms more often among their affected children. The intrafamilial analysis we used might account for the different outcome from that in other studies. ${ }^{34}$ Additional data are required to clarify the influence of events in early childhood on the development of inflammatory bowel diseases.

This work was supported by a grant from the Canadian Foundation for Ileitis and Colitis. PS received a career scientist award from the Ontario Ministry of Health, and SK received a clinical research fellowship from Nordic Laboratories.

1 Chandra RK. Long-term health implications of mode of infant feeding.

Nutr Res 1989;9:1-3.
Koletzko S, Sherman P, Corey M, Griffiths A, Smith C. Role of infant feeding $\frac{\bar{\sigma}}{}$

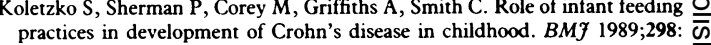
1617-8.

3 Gilat T, Hacohen D, Lilos P, Langman MJS. Childhood factors in ulcerative colitis and Crohn's disease: an international cooperative study. Scand $\mathcal{F}$ \%
Gastroenterol 1987;22:1009-24.

4 Whorwell PJ, Holdstock G, Whorwell GM, Wright R. Bottle feeding, early $\overrightarrow{0}$ gastroenteritis, and inflammatory bowel disease. BMJ 1979;i:382.

5 Acheson ED, Truelove SC. Early weaning in the aetiology of ulcerative colitis: a study of feeding in infancy in cases and controls. BMJ 1961;ii:929-33.

(Accepted 10 April 1991)

\section{Somatic component to myocardial infarction: three year follow up}

\section{A S Nicholas, D A DeBias, C H Greene}

\section{Philadelphia College of} Osteopathic Medicine, Philadelphia, Pennsylvania, United States 19131

A S Nicholas, Do, professor of osteopathic principles and practice

D A DeBias, PHD, professor of physiology and

pharmacology

C H Greene, PHD, professor of physiology

Correspondence to:

Professor DeBias.

$B M \mathcal{J} 1991 ; 302: 1581$ myocardial damage resolved.

\section{Patients, methods, and results} or too debilitated to participate.
In an earlier study we reported palpable changes in paravertebral tissue in patients with acute myocardial infarction. ${ }^{1}$ We undertook a follow up study to determine whether this somatic component altered as the

Eight of the 25 patients with myocardial infarction who participated in the initial study were available for follow up three to four years later. Of the others, nine had died and eight had moved away or were unwilling

The osteopathic physicians were unaware of the clinical diagnosis and were not allowed to talk to the patients in case this provided them with subjective information. As none of the patients had been admitted to hospital it was not necessary to simulate visual clues of treatment as had been necessary in the first study. The physicians noted palpable changes in the paravertebral soft tissue from $\mathrm{T} 1$ to $\mathrm{T} 8$ that matched predetermined qualitative descriptors, ${ }^{2-4}$ as in the

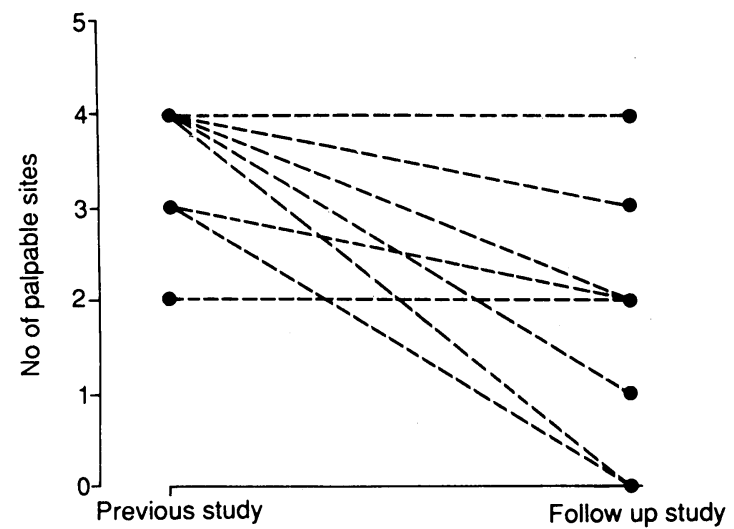

Change in number of palpable sites between TI and T4 on left side in eight patients with myocardial infarction followed up after three to four years previous study. Changes from $\mathrm{T} 1$ to $\mathrm{T} 4$ and from $\mathrm{T} 5$ to T8 on each side were evaluated statistically with the Wilcoxon matched pair signed rank test. The dif-O ferences in the findings between the two studies were 을 ranked and analysed.

The study was approved by the American Osteopathic Association Bureau of Research and the institutional review board of the Philadelphia College of Osteopathic Medicine. Written informed consent was $\vec{\bullet}$ obtained from all subjects.

The number of palpable sites between $\mathrm{T} 1$ and $\mathrm{T} 4$ on the left had fallen in six patients and was the same in two $\left(p<0.05\right.$; figure); the median change was $-1.5 \frac{\bar{\partial}}{0}$ (95\% confidence interval 0 to -4$)$. The other com-气 parisons between the two studies yielded $\mathrm{p}>0 \cdot 2$.

\section{Comment}

Our findings suggest that the somatic component of myocardial infarction and the insult to the myocardium ${ }_{\Sigma}^{-}$ may be anatomically and physiologically related. We are planning a prospective study of patients at high risk. of myocardial infarction to determine whether the somatic changes are present before infarction is clinic-ally apparent. Such an early predictor would speedo clinical management and might reduce mortality. The 30 year update of the Framingham study showed that unrecognised myocardial infarction is common $\tilde{\sigma}^{N}$ and has a poor prognosis. ${ }^{5}$ Clearer definition of the somatic component could help in the diagnosis of silent myocardial infarction and allow earlier clinicaln intervention.

We are indebted to the following coworkers: we Ehrenfeuchter, D Heilig, K England, and M Kirschbaum. We thank Dr Hyman Menduke for advice on statisticale analyses, Mrs Wanda L Young for computer generated: analyses, and Mrs Christine $M$ Donovan for typing the manuscript.

Nicholas AS, DeBias DA, Ehrenfeuchter W, et al Somatic component myocardial infarction. Br Med f 1985;291:13-7.

Beal MC. Palparory tesing for somatic dysunction in patients with ardio vascular disease. 7 Am Osteopath Assoc 1983;82:822-31.

Cox JM, Gorbis S, Dick LM, Rogers JC, Rogers FJ. Palpable musulokele findings in coronary artery disease: results of a double blind study J Am Osteopath Assoc 1983;82:832-6.

Beal MC, Kluber GE. Somatic dysfunction as a predictor of coronary artery disease. 7 Am Osteopath Assoc 1985;85(5):302-7.

$5 \mathrm{Kannel}$ WB, Abbott RD. Incidence and prognosis of unrecognized myocardial infarction: an update on the Framingham study. N Engl F Med 1984;311: 1144-7.

(Accepted 20 April 1990) 